\title{
The Diverse Uses of Fish-Poison Plants in Northwest GUYANA $^{1}$
}

\author{
Tinde VAN ANDEL
}

\begin{abstract}
Van Andel, Tinde (National Herbarium of the Netherlands, Utrecht University branch, P.O. Box 80102, 3508 TC Utrecht, the Netherlands). THE DiverSe Uses OF Fish-PoISON PlanTS IN NoRThweST GuYANA. Economic Botany 54(4):500-512, 2000. Although prohibited by law, fish poison plants are still widely used by indigenous tribes in Guyana. The latest ethnobotanical collections date from the first half of the 20th century and, from recent anthropological studies, it cannot be deduced whether the same species are still used today. The present study attempts to clarify the taxonomy and ethnobotany of the fish poisons, in particular those containing rotenone, currently used by Amerindians in northwest Guyana. Specimens were collected from 11 species known to be ichthyotoxic, both from wild and cultivated sources. It was found that fish poisons not only serve as a quick method of providing food in times of shortage, but also play an important role in magic rituals and traditional medicine. Particularly striking was the use of Lonchocarpus spp. and Tephrosia sinapou in the treatment of cancer and AIDS. Further ethnobotanical and pharmacological research should focus on the medicinal applications of rotenone-yielding plants.
\end{abstract}

Los Diversos Usos de los Barbascos en el Noroeste de GuYana. Aunque prohibidos por la ley, los barbascos aún son usados ampliamente por las tribus indígenas de Guyana. En dicha región, las colectas etnobotánicas más recientes datan de la primera mitad del siglo XX y desafortunadamente los estudios antropológicos contemporáneos no señalan los nombres científicos de las especies utilizadas. Este artículo tiene por objetivo aclarar la taxonomía y etnobotánica de los barbascos empleados actualmente por los amerindios del Noroeste de Guyana. Se colectaron muestras de once especies, cultivadas y silvestres, reconocidas como ictiotóxicas. Se encontró que los barbascos no solo proporcionan un método rápido para obtener alimento en tiempos de escasez, también son ingredientes importantes en rituales mágicos y como plantas medicinales. En particular es sorprendente el uso de Lonchocarpus spp. y Tephrosia sinapou en el tratamiento del cancer y SIDA. Las investigaciones etnobotánicas y farmacológicas futuras deben enfocarse a las aplicaciones médicas de las plantas que contienen rotenoides.

Key Words: fish-poison plants; Guyana; indigenous peoples; traditional medicine; cancer; AIDS; Lonchocarpus; Tephrosia; ethnobotany.

Although the use of certain plants to poison fish has been documented on all continents, the indigenous tribes of South America use the greatest variety of plant species (Acevedo-Rodríguez 1990; Howes 1930). Poisoning methods may vary from place to place, but they usually consist of throwing macerated material of ichthyotoxic plants into creeks or shallow ponds. After a while, the stupefied fish start to float to the surface, where they can be easily collected by hand or shot with bow and arrow.

One of the main chemical compounds of

\footnotetext{
${ }^{1}$ Received 14 October 1999; accepted 20 March 2000
}

ichthyotoxic plants is rotenone. This isoflavonoid is extremely toxic to cold-blooded animals, but less active in birds and animals. Rotenone is much more toxic to warm-blooded animals when applied directly in the bloodstream than when taken orally. Due to its low toxicity when ingested, fishes stupefied by rotenone can be eaten by humans without any adverse reaction (Acevedo-Rodríguez 1990). Rotenone causes respiratory depression in fish, forcing them to gasp for breath with wide-open gills at the water surface. The poison is also highly toxic to insects. Rotenone has two major advantages: (1) humans can digest it relatively safely, and (2) it is unstable in light and heat, loosing almost all its 
toxicity after 2-3 days (Hamid 1999; Leslie 1994; Matsumura 1985).

In contrast to other flavonoids, rotenone has a rather limited taxonomic distribution. It occurs mainly within the Fabaceae, especially in the genera Lonchocarpus, Paraderris, and Tephrosia. When rotenone was isolated for the first time from Peruvian Lonchocarpus roots by Clark (1929) and its effectiveness as an insecticide became known, a significant export trade in Lonchocarpus utilis A.C. Smith and L. urucu Killip \& A.C. Smith developed in Peru and Brazil. The roots, locally known as barbasco or cube, were processed industrially into insecticides (Krukoff and Smith 1937). As commercial extraction quickly depleted wild plants, they are now grown almost exclusively on plantations. The region around Iquitos (Peru) is currently the world's largest producer of Lonchocarpus (Rehm and Espig 1991). Nowadays, the dried, pulverized roots are gaining renewed interest, since natural insecticides with rapid biological degradation are well received by both ecologists and consumers.

The use of fish poisons by indigenous tribes in Guyana was described comprehensively in the first half of the 20th century (Archer 1934; Fanshawe 1948, 1953; Gillin 1936; Howes 1930; Martyn and Follett-Smith 1936; Roth 1924). Based on the idea of commercial trade, some planting trials with Lonchocarpus nicou (Aubl.) DC. and an unidentified Lonchocarpus species were carried out in Guyana's North-West District in 1929 (see Fig. 1). These species were identified later as $L$. martynii A.C. Smith and $L$. chrysophyllus Kleinh. (Krukoff and Smith 1937). However, due to the low rotenone content, the species never became an export product (Archer 1934; Martyn and Follett-Smith 1936). In their search for South American rotenoneyielding plants, Krukoff and Smith (1937) also considered the rotenone content of the Guyanese Lonchocarpus species too low to be commercially competitive with those of Peru and Brazil: the fresh roots of the Brazilian species contained $5-12 \%$ rotenone, while those of the Guyanese species L. martynii and L. chrysophyllus possessed only $2.4 \%$ of the compound.

Local Amerindians have apparently been cultivating ichthyotoxic plants for a long time. This can be deduced from field labels of early $L$. chrysophyllus collections from the upper Essequibo (A. C. Smith 2823) and Berbice regions
(Krukoff 7699) and from the early reports by Archer (1934) and Howes (1930) on the cultivation of the ichthyotoxic species Euphorbia cotinifolia L. (syn. E. cotinoides Miq.), Tephrosia sinapou (Bucholz) A. Chev. (syn. T. toxicaria (Sav.) Pers.), Clibadium sp., and Phyllanthus sp. in Guyana. In fact, this cultivation might even have a pre-Columbian origin, as species within these genera were already domesticated in Amazonia at the time of the first European contact (Chevalier 1925; Clement 1999).

Although prohibited by law since the 1950s, recent anthropological studies indicate that fish poisoning is still an important activity in the life of Guyanese Amerindians today (Forte 1996; Reinders 1993; Riley n.d.; Sullivan 1997). The indiscriminate poisoning of creeks and ponds, however, has caused a decline in fish stocks around Amerindian settlements and has increased mortality among cattle that drink from poisoned pools (Forte 1996; Forte, Pierre, and Fox 1992; Iwokrama 1998). Since these anthropological studies did not always combine the recording of local names with plant collections, it remains unclear which kinds of fish poisons are currently being used in Guyana. When collections did take place, specimens were often lost or could not be identified properly due to incomplete sampling, resulting in few reliable scientific names for the fish poisons mentioned by indigenous informants. Unfortunately, no recent, comprehensive studies on fish poisons have been conducted in Guyana, like the one by Moretti and Grenand (1982) in French Guiana. Furthermore, the scientific names listed in older publications are not always up-to-date and are often based on sterile collections (Martyn and FollettSmith 1936), making it rather difficult to compare present-day plant use with that of the past.

Although reports from other countries have noted that plants with ichthyotoxic activity are also used as arrow poisons, soap substitutes, and medicines (Acevedo-Rodríguez 1990), little is known of these additional uses in Guyana. As stated above, few ethnobotanical studies have been conducted in Guyana (Austin and Bourne 1992), and not many authors have documented the use of fish poisons other than for stupefying fish or killing insects. This paper presents an overview of the ichthyotoxic plant species currently being used by three Amerindian tribes of northwest Guyana (Carib, Arawak, and Warao). Special attention is paid to the species' state of 


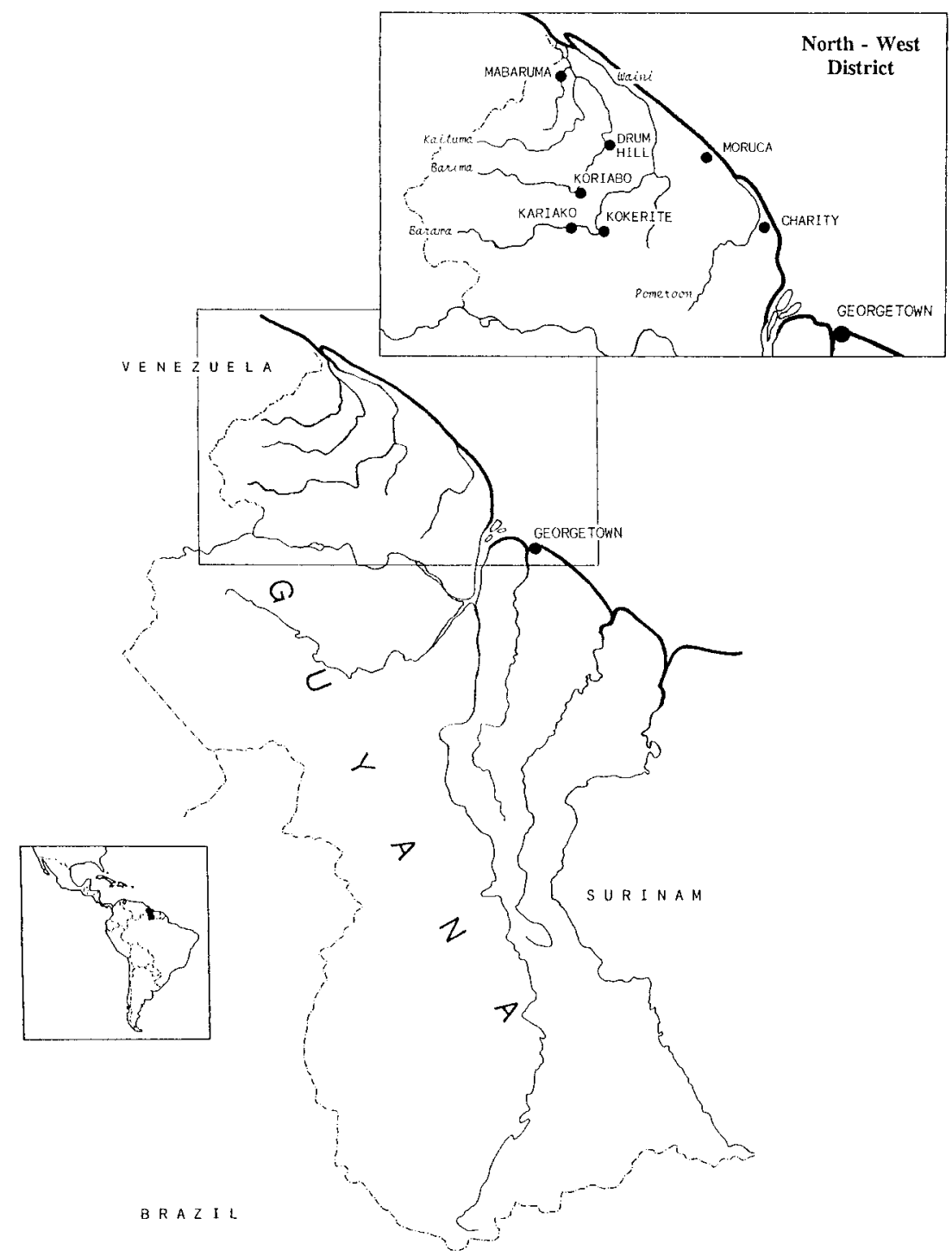

Fig. 1. Map of Guyana's North-West District. Illustration by Hendrik Rypkema.

domestication and their importance in activities other than fishing. Data discussed in this paper were collected during a wider survey of nontimber forest products in the region, carried out within the framework of the Tropenbos-Guyana Programme. Voucher specimens have been deposited in the Herbarium of the University of Guyana (BRG) and the Utrecht branch of the National Herbarium of the Netherlands (U). The preliminary results of this study point out that, in present-day Amerindian life, fish poisons are not only important in providing food, but also play an important role in religion and traditional medicine.

\section{Fish Poisons Presently Used in NorThWEST GuYANA}

Specimens of 11 plant species used as fish poison were collected in northwest Guyana: five are only known from cultivated sources, four are harvested exclusively in the wild, and two are collected in the forest, but also propagated by cuttings taken from wild plants (see Table 1).

The fast-growing shrubs Clibadium surina- 


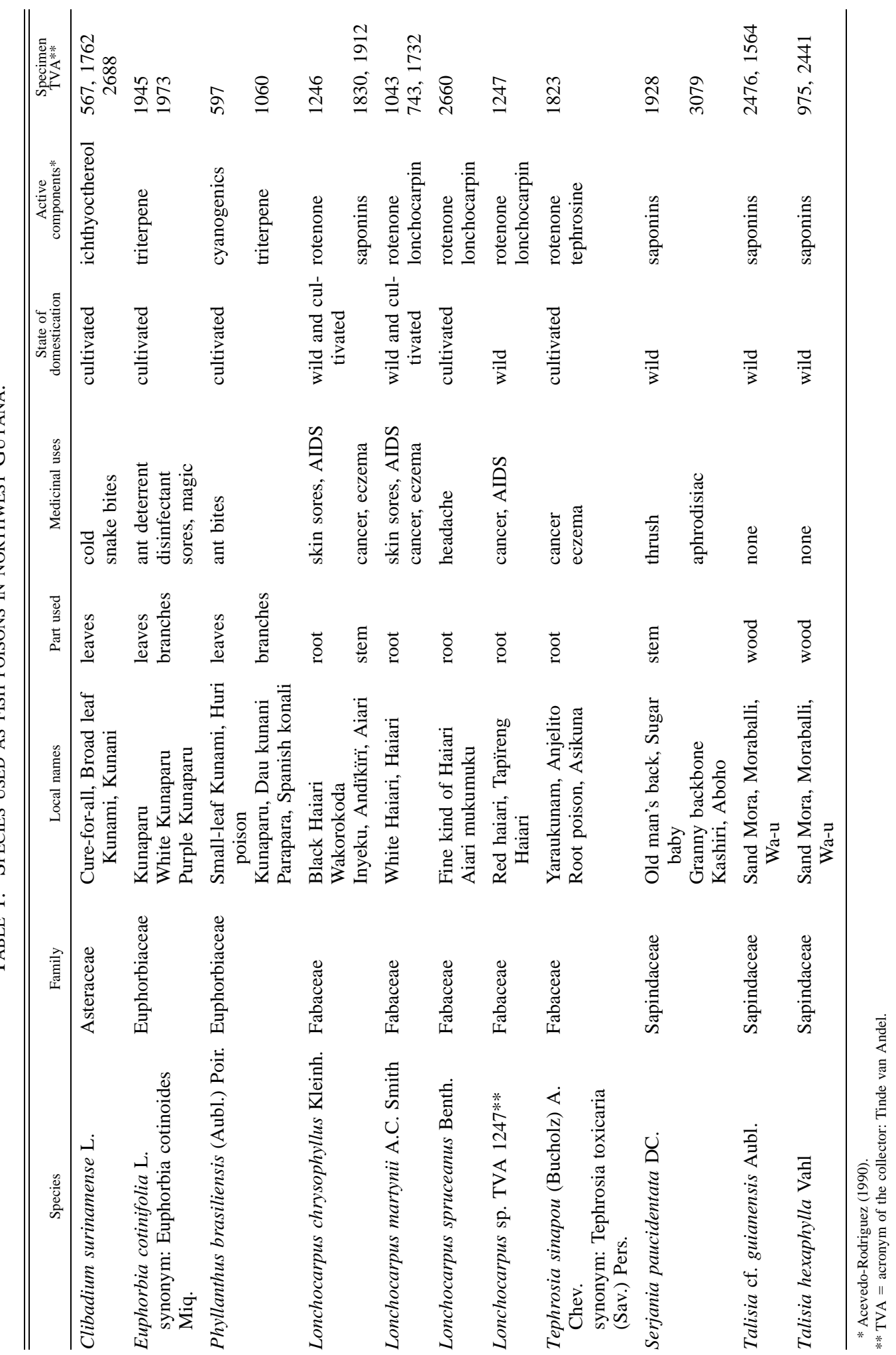


mense and Phyllanthus brasiliensis are the most frequently used species to poison fish and are cultivated on the majority of Amerindian farms. A large basket full of leaves and branches is stuffed into a hole in the ground and crushed with a wooden pestle into a pulpy mass. The pulp is then simply thrown in the water or immersed along with the basket in a creek. According to informants, both species are capable of stunning only small fish and Phyllanthus brasiliensis is especially effective in catching Huri (Hoplias malabaricus). P. brasiliensis seems to be more potent when in flower or fruit (Acevedo-Rodríguez 1990; Roth 1924), therefore adult individuals, which are fertile most of the time, are most often used. Two cultivars were collected (one with green twigs and leaves and one with purplish stems). However, local users did not indicate any difference in efficacy between the two types. Clibadium and Phyllanthus occasionally escape from cultivation. The wild Clibadium is considered less poisonous and thus less powerful.

Carib Indians living along the Barama River (see Fig. 1) prepare kunami balls as fish poison. They first pound Clibadium leaves mixed with fresh (grated, but unsqueezed) cassava roots, then roll the mixture in leaves and bake it in a fire. Ashes of burnt Cecropia leaves and sometimes some peppers are added to the sticky paste, after which the mass is pounded in a mortar and kneaded into small balls. These balls are then rolled in flour to make them white and, thus, more visible to fish. When the kunami balls are thrown in the water, the fish eat them whole. Soon thereafter the fish start floating belly upwards.

Leaves of the shrub Solanum leucocarpon L.C. Rich. ex Dunal are sometimes mixed with Clibadium leaves. Since S. leucocarpon is only used in combination with another poison, it is not clear whether the plant itself contains ichthyotoxic ingredients. Therefore, it was not included in the table.

Tephrosia sinapou used to be one of the most common and effective piscicides in Guyana (Martyn and Follett-Smith 1936). Today, however, the shrub is only sporadically grown in northwest Guyana. Its black roots are pounded with a club or hammer and thrown in a creek, giving the water a whitish appearance. The poison is capable of killing hassa (Hoplosternum littorale) and yarau (Hoploerythrinus unitaeniatus), but hardly affects huri.

Euphorbia cotinifolia is probably the most toxic of all fish poisons. Its white latex causes blisters on human skin and temporary blindness if it comes in contact with the eyes. A few branches are placed in an old basket and beaten after being submerged in the water to prevent the poisonous latex from touching the body. Guts and scales should be removed from the fish immediately, so that the toxic triterpenes cannot affect the consumer (Killip and Smith 1935; Prance 1972). The fish tend to spoil even before they are removed from the water (Fanshawe 1953). For this reason, E. cotinifolia is rarely used as fish poison anymore. Every now and then, however, the species is cultivated in home gardens for ornamental, medicinal, or magical purposes. Two cultivars were collected for this study: one with green twigs and leaves (white kunaparu) and one reddish variety called purple kunaparu. The latter is said to be more poisonous than the white variety. Although E. cotinifolia will be divided in two subspecies in the near future (Christenhusz 1999), both cultivars fall within the same subspecies.

The wild plants providing the most effective fish poisons belong to the genus Lonchocarpus, locally known as haiari. In the past, there was some confusion about the exact species utilized, since the absence of flowering and fruiting material on the collected specimens made it difficult to identify them to species level (Howes 1930; Killip and Smith 1935; Krukoff and Smith 1937; Moretti and Grenand 1982). In fact, the identification of Lonchocarpus remains a problem, as no comprehensive revision of the genus exists for South America. Fortunately, taxonomic research is currently being conducted on this genus by Sousa Sánchez of the National Herbarium of Mexico (MEXU) and by Poppendieck of the Institüt für Allgemeine Botanik in Hamburg (HBG).

Four species of Lonchocarpus are used as fish poison in northwest Guyana. The black haiari, Lonchocarpus chrysophyllus (see Fig. 2) is considered the strongest of all. The stem of this large canopy liana can reach a diameter of 20 $\mathrm{cm}$ and is distinguished vegetatively from the other species by having darker twigs and leaves and fine golden hairs on young twigs and leaves. Both the stems and roots are used for poisoning, although the latter are said to be stronger. Black 


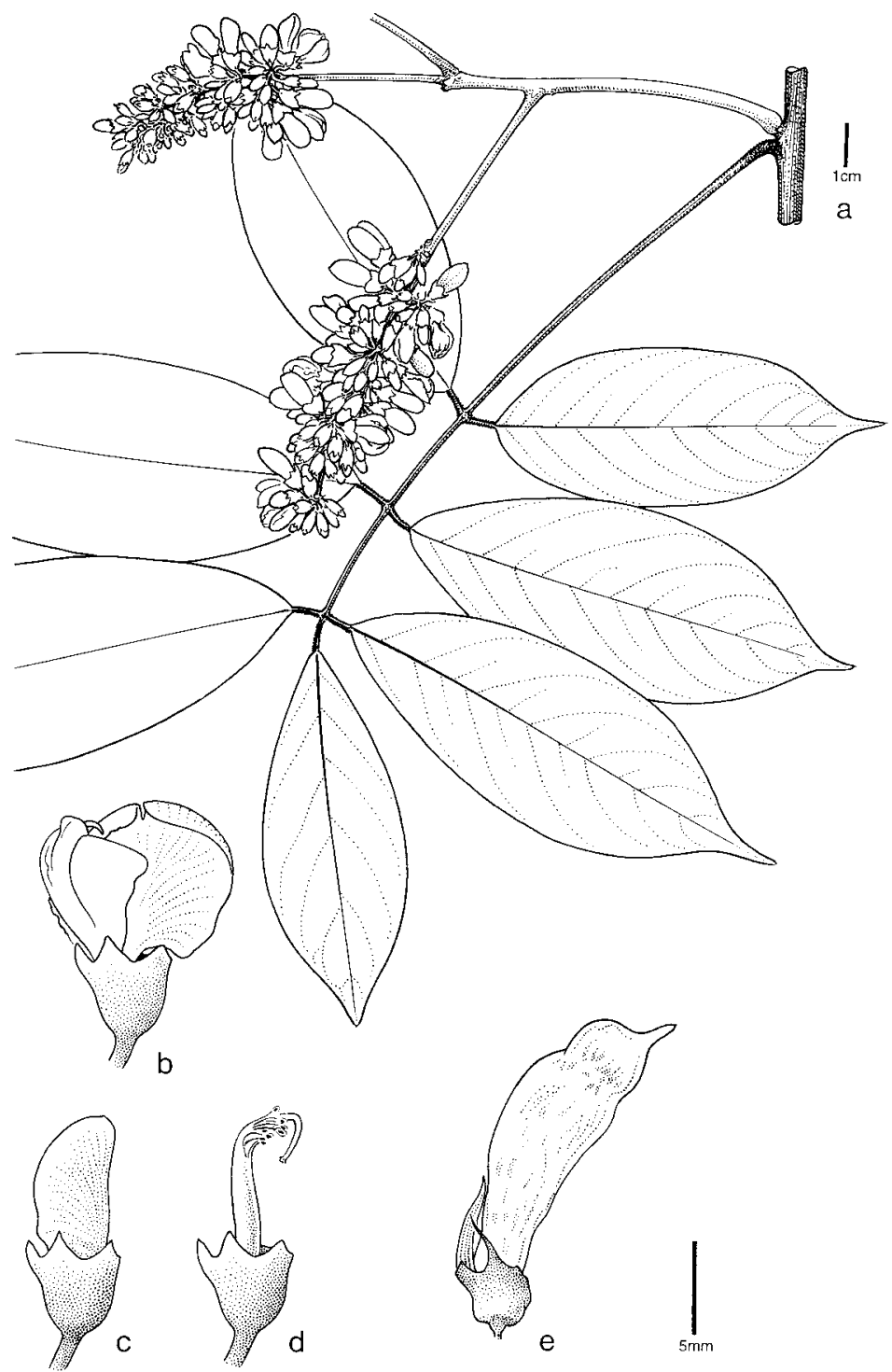

Fig. 2. Black haiari, Lonchocarpus chrysophyllus. (a) flowering branch; (b) flower; (c) flower with wings removed; (d) flower with wings and keel removed; (e) unripe fruit. Ripe pods were not seen. Illustration by Hendrik Rypkema.

haiari is particularly efficient in stunning yarau. In the past, several other species were collected in Guyana under the name black haiari, e.g., $L$. rariflorus Mart. ex Benth. (A.C. Smith 2161) and L. nicou (Aubl.) DC. (Killip and Smith 1935). These species were not found during the present study.

The white haiari, Lonchocarpus martynii, is also a canopy liana, but has glabrous, lighter colored twigs and leaves. Only its roots contain the poisonous substance. Most collections of white haiari in the North-West District were identified as $L$. martynii, although $L$. nicou was collected under that name by Martyn and Follett-Smith (1936). The fine kind of haiari, L. spruceanus, is less known. This shrubby tree with its small leaves was observed only once on an abandoned farm in a Warao village along the Waini River. The rare red haiari was identified by Fanshawe (1948) as L. rariflorus, while another red haiari, 


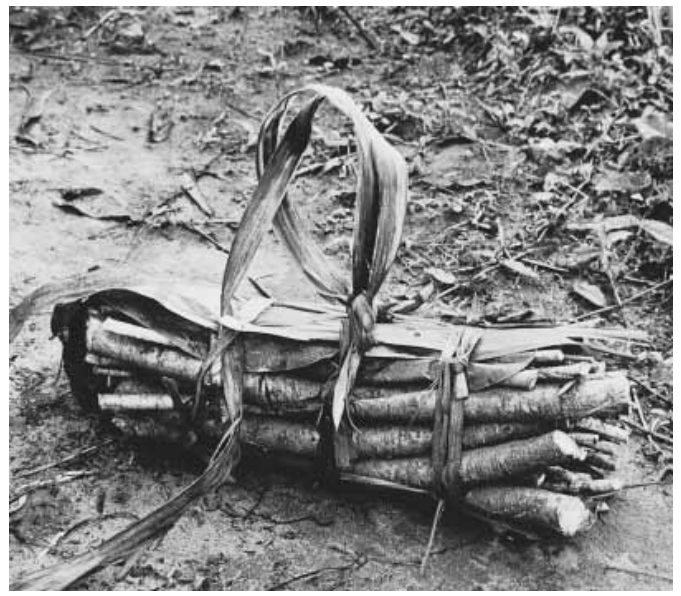

Fig. 3. Bundle of Lonchocarpus roots collected from the forest, sufficient to poison an medium-sized creek.

collected along the Barima River by Archer (2520a), was identified in 1997 as L. utilis. A sterile specimen of red haiari was collected in Barama during the present study, but could not be identified to the species level (Lonchocarpus sp. TVA 1247).

The lateral roots of the haiari species are dug out and cut into pieces about $75 \mathrm{~cm}$ long (see Fig. 3). About 15 pieces are needed to poison an average creek. The roots are pounded with a wooden club on a trunk at the water's edge, preferably at the head of a forest creek (see Fig. 4).

After a while, a white, milky juice is released from the roots. The shredded fibers are then soaked in the water and the creek bottom is stirred with the feet in order to mix the mud with the poison. After several minutes, the first fish start coming to the surface. Although clearly stupefied, they disappear quickly when touched: it requires great expertise to kill these fish by striking them on the head with a machete. Larger fish like the haimara (Hoplias macrophtalmus) tend to sink when poisoned, forcing the fishermen to dive down and catch them by hand. To intercept fish floating downstream, a wicker fence made from mokru stems (Ischnosiphon spp.) is used to close off the creek mouth. If the fish reach fresh river water, the poison rapidly loses its effect. Baskets full of fish are caught with this method, and the surplus is often sold to villagers. Local fishermen advise washing the fish well and carefully removing the gills, "because that is what sucks up the poison."

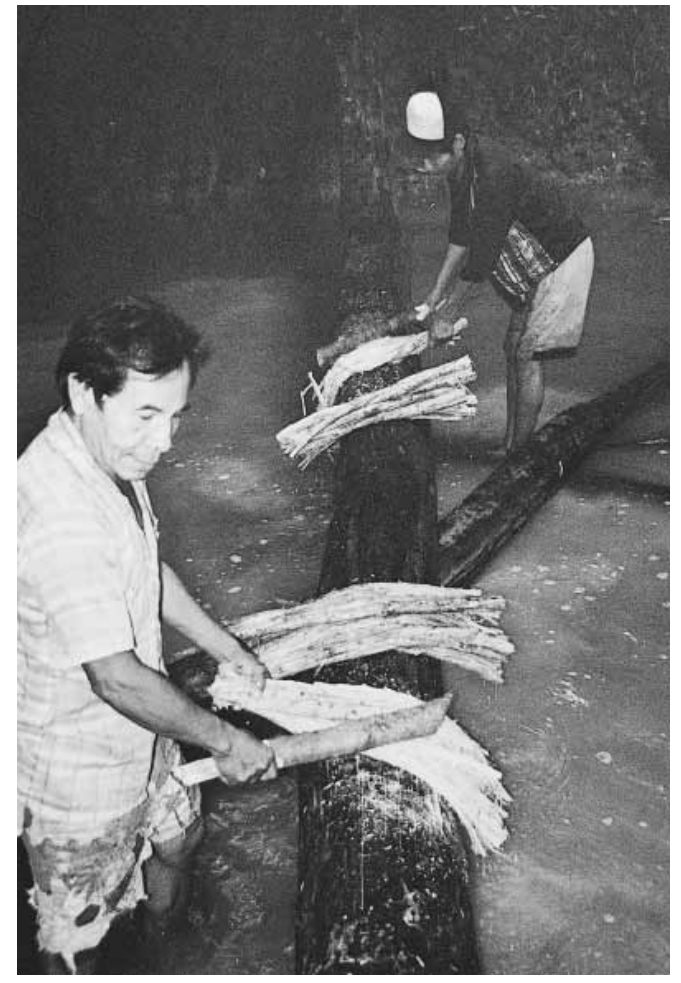

Fig. 4. Beating the roots till they become fibrous and release the white juice that contains the rotenone.

Deeper in the interior where population pressure is relatively low, informants said they needed one day to collect the required amount of haiari to poison a creek. As quite a distance must be covered in the well-drained upland forest to find enough roots, the search is often combined with hunting or gold prospecting. Cuttings from L. martynii and L. chrysophyllus are occasionally planted in farms or home gardens. In the more densely populated coastal villages, wild haiari lianas have become so scarce that they are predominantly found in cultivation. It seems that the wild lianas are wrenched from the ground and do not survive the harvesting of the roots. Much more care is taken with cultivated plants; in fact, some of the plants that are now large lianas were planted in home gardens more than 20 years ago. Cuttings are planted in the ground during the wet season, in a shadowy place with a fruit tree as support. Owners of a haiari liana sporadically allow their neighbors to dig out some roots to use for poison.

The ribbed liana Serjania paucidentata is occasionally used by Arawaks and Warao to poi- 
son small streams or ponds in the coastal savannas. The stem is chopped into small pieces and the saponins released from the bark and wood kill the smaller fish by asphyxiation (Moretti and Grenand 1982).

The name sand mora has been given to two rare tree species in mixed upland forests: Talisia hexaphylla and T. cf. guianensis. According to Carib Indians, the wood is extremely poisonous. In order to catch fish, wood chips are thrown into the water and apparently turn it pitch black. Guts, scales, and skin of the fish must be removed as quickly as possible and the flesh thoroughly cleaned with lime to avoid poisoning the consumer. Although used more commonly in the past (Gillin 1936), people are now reluctant to use these species. The wood is even considered to be too poisonous for use in house construction or as firewood.

Apparently, the various poisons all have a different mode of action and vary in their ability to stupefy certain species of fish. Otherwise, why would people make the effort to walk large distances to collect Lonchocarpus, if Phyllanthus or Clibadium were available within the village boundaries and had the same effect? Unlike Moretti and Grenand (1982), no correlation was found between the salinity of the water and the type of fish poison used. Many other Guyanese plant species have been mentioned as fish poisons (Fanshawe 1948, 1953; Killip and Smith 1935), some of which occur widely in northwest Guyana. Many are not, however, utilized by the local population for this purpose, e.g., Mora excelsa Benth., Bauhinia spp., Alexa imperatricis (R. Schomb.) Baill., Clathrotropis brachypetala (Tul.) Kleinh., Gustavia augusta L., Macrolobium acaciifolium Benth., Paullinia pinnata L., Pentaclethra macroloba (Willd.) Kuntze, and Ryania pyrifera (L.C. Rich.) Sleumer \& Uittien.

\section{The Importance of Fish Poisons IN AMERINDIAN SOCIETY TODAY}

Poisoning is considered to be a productive fishing method in northwest Guyana, more effective than hooks or fish traps (Sullivan 1997). Nets, however, are preferred above poisoning and are used most frequently, although not everyone can afford them. It seems that poisoning is more important in traditional, isolated settlements, where $16 \%$ of the fishermen said they used this method most. In larger and more westernized villages, only $5.3 \%$ of the fishermen said they used poison more than any other fishing method (Sullivan 1997).

In gold mining areas where land dredges and hydraulic pumps have disrupted the riverbeds and increased water turbidity and pollution, fish in the large rivers have become so scarce that people are being forced to revert to poisoning forest creeks. Pounding holes for kunami leaves can be seen all along the creeks bordering the villages. In densely populated Amerindian areas, where fish tend to be overharvested, poisoning remains an easy option for poor families unable to buy fish or fishing gear. These people are very well aware that poisoning implies the killing of many small fish, but often see it as an emergency method to relieve hunger. Or as one informant put it: "Without this kunami, Amerindians would never live."

Roots of L. chrysophyllus and L. martynii are regularly sold for US\$ 0.10 per $\mathrm{lb}$ at the regional market in Mabaruma. Since approximately $25 \mathrm{lb}$ of roots are needed to poison a medium-sized creek, then US\$ 2.5 are needed per event. Buyers are Amerindians living in the brackish coastal swamps, where Lonchocarpus does not grow. They live predominantly from commercial palm heart harvesting and many have abandoned the practice of slash-and-burn agriculture (van Andel, Huyskens and Bröker 1998). Since home gardens are not common in these communities, Clibadium and Phyllanthus are seldom grown. Even though the Guyanese law prohibits the use of fish poison, people are only incidentally arrested for using it. In fact, in the largest Amerindian reserve of Santa Rosa (Moruca River), Clibadium and Phyllanthus are grown in the vicinity of the police station. Deeper in the interior, there is no control at all.

\section{Fish Poisons in Traditional MEDICINE}

Fish poisons are used in various traditional remedies, not only by the indigenous population, but also by the Creoles and East Indians living in Guyana. The juice from the leaves of Clibadium surinamense is squeezed into a cup, mixed with a few drops of kerosene, and drunk as a remedy for snake bites, in particular bites by the deadly labaria or fer-de-lance (Bothrops asper) and the bushmaster (Lachesis mutus). The kerosene is probably added to extract alkaloids that are only fat-soluble. Dried branches are boiled in water and drunk as tea to treat colds. A de- 
coction of the whole plant is also used to wash out cuts and sores.

The leaves of Serjania paucidentata are boiled and given to babies suffering from thrush. Thrush is an infection of the mouth caused by the fungus Candida albicans, resulting from unhygienic milk bottles or dirty nipples (LachmanWhite, Adams, and Trotz 1992). The liana is also an ingredient of a popular aphrodisiac. For that purpose the woody stem is boiled with one or more of the following products: the roots of cockshun (Smilax schomburgkiana Kunth), kupa (Clusia spp.), and sarsparilla (Dioscorea trichanthera Gleason), the wood of kapadula (Tetracera, Pinzona, or Doliocarpus sp.), granny backbone (Curarea candicans (L.C. Rich.) Barneby \& Krukoff), and devildoer (Strychnos spp.), and the bark of locust (Hymenaea courbaril L. var. courbaril). These "builders" are said to protect against a variety of diseases and stimulate the sexual activity of both men and women. Medicinal herb stalls in Georgetown sell dry branches of Clibadium surinamense, wood of Serjania paucidentata, and a wide assortment of ready-made tonics and aphrodisiacs.

The macerated leaves of Phyllanthus brasiliensis are heated above a fire and applied as a poultice to the painful bites of the munuri ant (Pariponera clavata). The biting sap of Euphorbia cotinifolia is dropped on inflamed fingernails to get rid of the infection. A whole branch of $E$. cotinifolia is boiled in water into a thick syrup and applied to persistent skin sores caused by bacteriosis or leishmaniasis parasites.

By far the most remarkable medicinal application of fish poisons is the use of Lonchocarpus and Tephrosia roots in the treatment of cancer and AIDS. Concentrated root juice is applied externally to sores and lesions caused by skin cancer and AIDS. The poison is also dissolved in a bucket of water and used to bathe patients with skin cancer and eczema. Small doses of the poison, varying from three drops in a glass of water to one spoonful of undiluted sap, are taken orally in the treatment of AIDS and cancer of the skin, stomach, liver, and intestines. These medicines are taken on a daily basis. People believe the fish poison kills the germs causing cancer and AIDS. People from different ethnicity and provenance in northwest Guyana are enthusiastic about the healing properties of the fish poisons. They tell stories about miraculous recoveries after using this treatment, both of termi- nally ill patients and people in the early stages of the disease. AIDS patients from Georgetown have even been reported to visit Amerindian reserves, seeking to be cured with haiari poison.

Only the roots of Lonchocarpus chrysophyllus, L. martynii, and Tephrosia sinapou are used in this treatment. The side effects of the poison are obviously quite bad. Incidents have been reported of desperate patients taking an overdose of a whole calabash full of haiari juice. After suffering from heavy nausea, fainting, and vomiting for a few days, the patients were said to recover and feel much better. In several cases, this therapy extended the lives of terminally ill patients for several months, long after the hospital had given up on them. However, since most patients could no longer be traced back, the exact diagnosis and history of their illness could not be studied during this investigation.

The juice of Lonchocarpus spruceanus is not mentioned as a cancer medicine, but it is applied to the forehead to relieve headaches. The red haiari (Lonchocarpus sp. TVA 1247) is also not associated with cancer treatment. LachmanWhite, Adams, and Trotz (1992) reported that the bark of L. martynii is used in coastal Guyana as a tranquilizer and a decoction of the root to treat venereal diseases. The stems and roots are roasted, ground, and mixed with oil and applied externally for the relief of pain. The authors also mentioned that the bark of L. chrysophyllus is used to treat labaria bites and that a decoction of the bark mixed with the stems of Costus scaber Ruiz \& Pav., Justicia pectoralis Jacq., and a little alum is used as an suppressant for severe coughs. None of these uses, however, were mentioned in northwest Guyana.

\section{AdDitional USES OF ICHTHyotoxic Plants}

In the 1930s, Gillin (1936) saw Caribs pouring haiari juice around the roots of their tobacco plants to kill the grubs infesting them. Nowadays, the use of fish poisons as insecticides in northwest Guyana is limited. High quantities of haiari juice are said to kill leaf cutter ants (Atta sp.), but people prefer to use the fruit pulp from the abundantly growing herb Renealmia orinocensis Rusby for this purpose. The toxic sap of Euphorbia cotinifolia is also mentioned as an effective repellent for these ants (Dance 1881, Grenand, Moretti, and Jacquemin 1987; Reinders 1993). However, people said they did not 
like to jam the branches of this plant into ants nests, because they feared skin injuries by the vesicant sap. The custom of planting these shrubs in cassava fields to prevent the ants from building their nests was not observed during this study. The indigenous people of northwest Guyana rub the oil of Carapa guianensis Aubl. or the bark juice of Alexa imperatricis (Schomb.) Baill. on their bodies to eradicate lice and scabies instead of using fish poisons like other indigenous groups (Acevedo-Rodríguez, 1990; Lachman-White, Adams, and Trotz 1992; Moretti and Grenand 1982). Nevertheless, the possibilities of producing cheap insecticides from haiari roots to handle local insect plagues should not be underestimated.

Finally, fish poisons play a role in the magical beliefs and practices of Amerindian life, although this is seldom admitted by informants when asked. If somebody dies unexpectedly under suspect circumstances, people may believe that the person was poisoned or murdered, or that death was caused by a magic spell cast by an enemy. To find the offender, a cross of $E \mathbf{E}$ phorbia cotinifolia leaves is carefully placed in the coffin before the deceased is laid down in it. A few days after the funeral, the murderer will betray himself by contracting a terrible itch over his body, which will subsequently lead to his death. Despite its vesicant latex, this might be one of the reasons Euphorbia cotinifolia is still cultivated.

An evil spirit much feared by many Amerindian tribes is the Kanaima, a ruthless murdering ghost who seeks innocent victims in order to practice his revenge for injustice done to him in the past. To complete his task, the Kanaima must visit the grave of its victim and suck the fluids from the dead body through a hollow reed inserted in the ground. If he does not succeed in drinking the liquids of the deceased, he will die a horrible death (Gillin 1936). To deceive and frighten the Kanaima, a bowl with haiari juice mixed with some body fluids of the dead person is placed on the grave. This custom is still sporadically practiced among the Barama River Caribs when a person is believed to have died from an attack by the Kanaima spirit.

\section{Discussion AND Conclusions}

Although more than 3000 plants are used in various parts of the world for the treatment of cancer (Hartwell 1967-1971), few South Amer- ican fish poisons appear on this list. Kosteletzky (1831-1836) mentions the use of Tephrosia sinapou roots to combat tumors and scirrhosities in Brazil, while the roots of the Brazilian Lonchocarpus peckoltii Wawra have been reported to treat glandular tumors (Peckolt 1868). Peculiarly, some plants with proven antitumor activity (Hartwell 1976) are used by the Guyanese to treat diseases other than cancer, e.g., Catharanthus roseus (L.) G. Don is prescribed for diabetes and heart failure, Allamanda cathartica L. for constipation, and Heliotropum indicum L. for venereal diseases. However, this might be explained by the fact that the alkaloids with antitumor activity are present in lower concentrations than other effective chemical compounds in these plants.

Spjut and Perdue (1976) screened 254 ichthyotoxic species, belonging to 64 plant families from all over the world, for anticancer properties. They found that some $39 \%$ of the species and $66 \%$ of the 158 genera proved to be active against tumors. Unfortunately, the authors did not provide a list of the species that were screened nor the outcome of the tests. They just gave a number of references they used to select plants. Howes (1930) is the only author in this reference list that mentions fish poisons being used in Guyana. Since he cited Tephrosia sinapou, it is likely that this species was screened for its antitumor properties. Howes was unable to identify the black and white haiari to the species level; thus, it is possible that the Lonchocarpus species mentioned in this paper have never been screened for active compounds. Spjut and Perdue (1976) argue that most poisonous plants are likely to have antitumor properties, especially those that are used in folk medicine, and that plants used as arrow poisons generally show a higher percentage of activity than fish poisons because of their effectiveness on warm-blooded animals.

The most known active ingredient of Lonchocarpus and Tephrosia is rotenone, which could be responsible for the alleged antitumor effect. Hartwell (1976) tested rotenone in a chemotherapy program of the National Cancer Institute and found it to be active against two types of tumors. He did not, however, consider this result particularly interesting. Fang and Casida (1998) reported that the 11 rotenoid constituents present in cube insecticide (made from Lonchocarpus utilis) showed clear anticancer activity in rats 
and mice. They also predicted that rotenoid concentrations would be potent in vivo against cultured human breast cancer cells. Intense cytotoxic activity of rotenone was observed in lymphocytic leukemia, carcinoma of the nasopharynx, and a number of human cancer cells, e.g., fibrosarcoma, lung cancer, colon cancer, melanoma, and breast cancer cell lines. Hamid (1999) therefore evaluated rotenone as a potential antitumor agent. However, Gozálvez and Merchan (1973) classified rotenone as an oncogenic agent that induced mammary tumors in $60-100 \%$ of the female rats injected with the substance. Apparently, numerous plant compounds have been shown to be oncogenic in animals, including certain antitumor agents. According to Farnsworth et al. (1976), this is not unexpected, since almost all clinically useful antitumor agents, both natural and synthetic, are also carcinogenic. It is known that rotenone has a rat oral LD50 that ranges from $60 \mathrm{mg} / \mathrm{kg}$ to $1500 \mathrm{mg} / \mathrm{kg}$, depending on the carrier (Leslie 1994). Although equivocal evidence exists on the carcinogenic activity of a diet containing rotenone fed to rats and mice (NCTR 1999), little is known about the carcinogenic effects of the oral intake by humans regularly eating poisoned fish.

Screening of fish-poison plants or rotenone against HIV or AIDS has not been mentioned at all in the literature. AIDS is spreading rapidly among female prostitutes in the Guyanese capital as a result of inadequate information services, the refusal of using condoms, and severe poverty. More than $10 \%$ of these women are Amerindian, a rather disproportionate number, since they form only $1 \%$ of the population in Georgetown (Carter 1993). The disease is brought into the interior by gold miners from the coast and by the prostitutes travelling with them to work in mining camps. Since interior clinics are generally ill-equipped with regard to staff and medicines, cancer and AIDS patients from remote areas often try to seek treatment in Georgetown hospitals. However, since these people are usually not aware they are infected with HIV until they start to develop AIDS, the disease is often in a late stage at the time of diagnosis. Furthermore, since most indigenous people can hardly manage to pay for an airplane ticket to the capital and often lack proper insurance, a long-term treatment for cancer or AIDS is not within their means. Many then return to their village to be treated with traditional medicine or to die in peace. The question remains whether treatment with rotenone-yielding fish poisons is only a desperate attempt to cure a mortal disease or indeed successful in relieving (some of) the symptoms of cancer and AIDS. Plants used in traditional medicine tend to have active ingredients and are far more likely to be useful as pharmaceuticals than randomly collected species (Mendelsohn 1997). Therefore, more detailed pharmacological research on the effectiveness of rotenone on cancer and HIV is strongly recommended.

More ethnobotanical studies are needed to find out if fish poisons are used for similar purposes in other parts of the Guianas. Detailed ethnobotanical studies have been carried out in French Guiana (Grenand, Moretti, and Jacquemin 1987; Moretti and Grenand 1982), while no such studies exist for Surinam and southern Guyana. Furthermore, since only six of the 18 species listed by Moretti and Grenand (1982) coincide with those used in northwest Guyana, a considerable diversity in utilization, species preference, and domestication can be expected within the Guianas. The region counts 15 species of Lonchocarpus, 25 species of Phyllanthus, and six species of Tephrosia (Boggan et al. 1997) and harbors several indigenous tribes knowledgeable about traditional medicine. Since vernacular names differ from place to place and one name may include several species, plant collections should definitely be included in this research. The genus Lonchocarpus is especially in need of good fertile collections. The use of ethnobotany to identify promising plants could substantially reduce the costs for the search of at least some pharmaceutical drugs (Mendelsohn 1997).

It can be concluded that fish poisons play an important role in the lives of indigenous tribes in northwest Guyana. They serve not only as a quick method of providing (emergency) food, but also as important ingredients in magical practices and traditional medicine. Conservationists calling for stricter laws and increased control on fish poisoning should realize that a ban on the cultivation and use of fish poisons would also deprive Amerindians of some essential medicines. Artificial fish ponds and community-based poisoning rules may be a better alternative than preventing people from using plants they have been gathering and growing for 
centuries-plants that one day might prove to have unexpected values for mankind in general.

\section{ACKNOWLedgments}

The author is most grateful to the inhabitants of Kariako, Koriabo, Moruca, Assakata, and Warapoka, Northwest Guyana for their collaboration and sharing of knowledge. This research was made possible by the Tropenbos-Guyana Programme. P. J. M. Maas, H. Maas-van de Kamer, and L. Cobb are acknowledged for critically reviewing this manuscript. M. J. Jansen-Jacobs and the rest of the Utrecht Herbarium Staff are thanked for their continuous support and guidance, especially H. Rypkema who provided the drawings. Special thanks are given to $\mathrm{H}$. $\mathrm{H}$. Poppendieck (HBG) and M. Sousa Sánchez (MEXU) for the identification of specimens. This research was funded by the European Union.

\section{Literature Cited}

Acevedo-Rodríguez, P. 1990. The occurrence of piscicides and stupefactants in the plant kingdom. Pages 1-23 in G. T. Prance and M. J. Balick, eds., New directions in the study of plants and people. Advances in Economic Botany 8. New York Botanical Garden, New York.

Archer, W. A. 1934. Fish poison plants of British Guiana, a preliminary list. Agricultural Journal of British Guiana 5(3):204-206.

Austin, D. F., and G. R. Bourne. 1992. Notes on Guyana's medical ethnobotany. Economic Botany 46(3):293-298.

Boggan, J., V. Funk, C. Kelloff, M. Hoff, G. Cremers, and C. Feuillet. 1997. Checklist of the plants of the Guianas (Guyana, Surinam, French Guiana), $2^{\text {nd }}$ Edition. ORSTOM, Smithsonian Institution and Centre for the Study of Biological Diversity. University of Guyana, Georgetown.

Carter, K. 1993. AIDS: dying to make a living. Guyana Review 7:21-25.

Chevalier, A. 1925. Sur les Légumineuses de la Tribu des Téphrosiées cultivées dans les pays tropicaux pour capturer le poisson: leurs usages et leur distribution géographique. Comptes rendus de l'Academie desSciences CLXXX:1520-1523.

Christenhusz, M. J. J. 1999. The genera Euphorbia, Pedilanthus and Macaranga in the Guianas. Internal report Herbarium Utrecht University, Utrecht.

Clark, E. P. 1929. The occurrence of rotenone in the Peruvian fish poison 'cube'. Science 70:478-479.

Clement, C. R. 1999. 1492 and the Loss of Amazonian Crop Genetic Resources I. The relation between domestication and human population decline. Economic Botany 53(2):188-202.

Dance, C. H. 1881. Chapters from a Guianese logbook. Demerara.

Fanshawe, D. B. 1948. Forest products of British Guiana, part II. Minor Forest Products. Forestry Bulletin No. 2. Forestry Department, Georgetown.

. 1953. Fish poisons of British Guiana. Kew Bulletin 2:239-240.

Fang N., and J. E. Casida. 1998. Anticancer action of cube insecticide: correlation for rotenoid con- stituents between inhibition of NADH: ubiquinone oxidoreductase and induced ornithine decarboxylase activities. Proceedings of the National Academy of Sciences 95(7):3380-3384.

Farnsworth, N. R., A. S. Bingel, H. H. S. Fong, A. A. Saleh, G. M. Christenson, and S. M. Saufferer. 1976. Oncogenic and tumor-promoting spermatophytes and pteridophytes and their active principles. Cancer Treatment Reports 60:1171-1214.

Forte, J. 1996. Macushi lifestyle and biodiversity use. Iwokrama International Rainforest Programme and Amerindian Research Unit. University of Guyana, Georgetown.

L. Pierre, and D. Fox. 1992. The material culture of the Wapishana people of the South Rupununi savannahs in 1989. Amerindian Research Unit. University of Guyana, Georgetown.

Gillin, J. 1936. The Barama River Caribs of British Guiana. Papers of the Peabody Museum of Archaeology and Ethnology 14(2).

Gozálvez, M., and J. Merchan. 1973. Induction of rat mammary adenomas with the respiratory inhibitor rotenone. Cancer Research 33:3047.

Grenand, P., C. Moretti, and H. Jacquemin. 1987. Pharmacopées traditionelles en Guyane. Créoles, Palikur, Wayãpi. Collection Mémoires, No. 108. ORSTOM, Paris.

Hamid, A. 1999. Derris Lour. Pages 234-242 in L. S. de Padua, N. Bunyapraphatsara and R. H. M. J. Lemmens, eds., Plant Resources of South-East Asia 12(1): medicinal and poisonous plants 1. Backhuys Publishers, Leiden.

Hartwell, J. L. 1967-1971. Plants used against cancer. A survey. Lloydia 30:379-436, and ten additional installments ending with 34:386-437. - 1976. Types of anticancer agents isolated from plants. Cancer Treatment Reports 60:10311067.

Howes, F. N. 1930. Fish poison plants. Bulletin of Miscellaneous Information Kew 4:129-152.

Iwokrama. 1998. Community-based wildlife management in the North Rupununi. Proceedings of a workshop 2-6 April 1998. North Rupununi District Development Board and Iwokrama International Centre for Rain Forest Conservation and Development, Georgetown.

Killip, E. P., and A. C. Smith. 1935. Some American plants used as fish poisons. U.S. Department of Agriculture, New York Botanical Garden, New York.

Kosteletzky, B. F. 1831-1836. Allgemeine medizinisch-pharmazeutische Flora, Vol. 1-6. Borrosch and André, Prague.

Krukoff, B. A., and A. C. Smith. 1937. Rotenoneyielding plants of South America. American Journal of Botany 24(9):573-587.

Lachman-White, D. A., C. D. Adams, and U. O. Trotz. 1992. A guide to the medicinal plants of 
coastal Guyana. Commonwealth Science Council, Technical Publications Series 225, London.

Leslie, A. R., ed. 1994. Handbook of integrated pest management. Lewis Publishers Inc., Washington D.C.

Martyn, E. B., and R. R. Follett-Smith. 1936. The fish poison plants of British Guiana, with special reference to the genera Tephrosia and Lonchocarpus. Agricultural Journal of British Guiana 7(3): 154-159.

Matsumura, F. 1985. Toxicity of insecticides. Plenum Press, New York.

Mendelsohn, R. 1997. Valuing undiscovered pharmaceuticals in tropical forests. Notes on Economic Plants. Economic Botany 51(3):328.

Moretti, C., and P. Grenand. 1982. Les nivrées ou plantes ichthyotoxiques de la Guyane Française. Journal of Ethnopharmacology 6:139-160.

National Center for Toxicological Research (NCTR). 1999. Tumorogenic potential of rotenone and its specificity for mammary tissue, experiment No. 216. Available on the world-wide web: http:// ntp-server.niehs.nih.gov/htdocs/LT-Studies/ TR320.html.

Peckolt, T. 1868. Analyses de Materia Medica Brasileira. E. and J. Laemmert, Rio de Janeiro.

Prance, G. T. 1972. Ethnobotanical notes from Amazonian Brazil. Economic Botany 26(3):221-237.

Rehm, S., and G. Espig. 1991. The cultivated plants of the tropics and subtropics. Institute of Agronomy in the Tropics. Verlag Josef Margraf, Göttingen.
Reinders, M. 1993. Medicinal plants and their uses and the ideas about illness and healing among the Warao of Guyana. MSc thesis, Department of Cultural Anthropology, Utrecht University, Utrecht.

Riley, M. n.d. Traditional remedies, indigenous knowledge and intellectual property rights: the current status and possible future of the ethno-medicine of the Makushi Amerindians. Paper presented at workshop Carib Studies in the Guianas: Ethnobotany, Language and Culture. 31 Aug.-1 Sept. 1998. Amerindian Research Unit and Tropenbos-Guyana, Georgetown.

Roth, W. E. 1924. An introductory study of the arts, crafts and customs of the Guiana Indians. 38th Annual Report of the Bureau of American Ethnology. Smithsonian Institution, Washington, D.C.

Spjut, R. W., and R. E. Perdue. 1976. Plant folklore: a tool for predicting sources of antitumor activity? Cancer Treatment Reports 60: 979-985.

Sullivan, C. 1997. Calculating the gross village product of an Amerindian village: the example of Assakata, N.W. Guyana, with particular reference to the contribution of GVP made by NTFP from the forest. Tropenbos Interim report 1997-4. Tropenbos Foundation, Wageningen.

van Andel, T. R., Huyskens, P. E., and K. C. A. Bröker. 1998. Palm heart harvesting in Guyana's North-West District: exploitation and regeneration of Euterpe oleracea swamp forests. TropenbosGuyana Interim Report 98-1. Herbarium Utrecht University, Utrecht. 